\title{
Discrimination study between the carcass and non- carcass components for interaction between gender, age, and production system in indigenous sheep
}

\section{Estudo de discriminação entre os componentes da carcaça e não da carcaça para interação entre gênero, idade e sistema de produção em ovinos indígenas}

\author{
Poliana Campos Burin ${ }^{1}$; Jessica de Oliveira Monteschio2; Ariadne Patrícia \\ Leonardo3; Marcio Rodrigues de Souza4; Adrielly Lais Alves da Silva5; Marcelo \\ Corrêa da Silva ${ }^{6}$; Carla Giselly de Souza ${ }^{7 *}$; Fernando Miranda de Vargas Junior ${ }^{8}$
}

\section{Highlights}

It is possible to discriminate the physiological stages by multivariate analysis.

The variables related to carcass yield are influenced by the physiological stage.

The cull ewes have heavier carcasses and are similar in quality to lambs and wethers.

\section{Abstract}

The objective of this work was to evaluate the yields, morphometric measures, carcass, and non-carcass components, and carcass regional and tissue composition of an indigenous sheep (Pantaneiro) of different physiological stages (gender, age, system production. Thirty sheep, eleven lambs, nine wethers, and ten cull ewes were used. The lambs were finished in feedlots, the wethers were maintained on pastures and supplementation, and the cull ewes were maintained on an extensive pasture system with mineral salt ad libitum. Slaughter ages were defined to simulate the most representative products and farming systems. Animals were slaughtered and classified as non- castrated lambs, wethers, and cull ewes. The criteria to slaughter lambs and wethers were the body condition, which ranged from 2.5 to 3.0. Cull ewes were

1 Dra. in Agronomy, Freelancer, Dourados, MS, Brazil. E-mail: poliana_burim@hotmail.com

2 Profa. Dra. at Animal Science Curse, Universidade Federal de Roraima, UFRR, Boa Vista, RR, Brazil. E-mail: jessicamonteschio@hotmail.com

${ }^{3}$ Dra. in Animal Science, Volunteer Researcher at the Universidade Federal de Grande Dourados, UFGD, Dourados, MS, Brazil. E-mail: aripatiileonardo@hotmail.com

${ }^{4}$ Prof. Ms., Instittuto Federal do Mato Grosso do Sul, IFMS, Dourados, MS, Brazil. E-mail: marcio. souza@ifms.edu.br

${ }^{5}$ Ms. in Zootechnics, Doctoral student at Postgraduate Program in Zootechnics, Universidade de São Paulo, ESALQUSP, Piracicaba, SP, Brazil. Email: drilais@hotmail.com

${ }^{6}$ Post-doctor at Postgraduate Program in Agribusiness, UFGD, Dourados, MS, Brazil. E-mail: marcelocorreadasilva@ hotmail.com

7 Post-doctor at Postgraduate Program in Zootechnics, UFGD, Dourados, MS, Brazil. E-mail: carlaxlsouza@yahoo. com

8 Prof. Dr., Postgraduate Program in Zootechnics, UFGD, Dourados, MS, Brazil. E-mail: fernandojunior@ufgd.edu.br

* Author for correspondence

Received: Mar. 10, 2021 - Approved: Aug. 27, 2021 
slaughtered based on negative pregnancy diagnosis, regardless of their body condition, which ranged from 4.0 to 4.5. All animals were slaughtered after 16-hours of fasting (solids). The ewes presented the greatest fat thickness, differing significantly from the lambs. The morphometric measures were higher in ewes and lambs. The muscle to fat ratio of the animal's cuts from different physiological stages presented no significant differences. The indigenous Pantaneiro sheep have good potential for meat production regardless of their physiological stages. The ewes stood out, presenting carcasses with good performance considering their potential and longer permanence in the herd due to their reproductive function.

Key words: Conservation. Locally adapted sheep. Morphometric measures. Sheep meat.

\section{Resumo}

O objetivo deste trabalho foi avaliar o rendimento, medidas morfométricas, componentes da carcaça e da não carcaça e a composição regional e tecidual da carcaça de ovelhas indígenas (Pantaneiro) de diferentes sistemas de produção, sexo e idade. Foram utilizadas trinta ovelhas, onze cordeiros, nove borregos e dez ovelhas de descarte. Os cordeiros foram terminados em confinamento, os borregos mantidos em pastagem e suplementação, e as ovelhas de descarte mantidas em sistema a pasto extensivo com sal mineral ad libitum. As idades ao abate foram definidas para simular os produtos e sistemas agrícolas mais representativos, cordeiros, borregos e ovelhas de descarte. Os animais foram abatidos e classificados como cordeiros não castrados, borregos e ovelhas de descarte. Os critérios para abate de cordeiros e borregos foram a condição corporal, que variou de 2,5 a 3,0. As ovelhas de descarte foram abatidas com base no diagnóstico de gestação negativo, independentemente da condição corporal, que variou de 4,0 a 4,5. Todos os animais foram abatidos após jejum de 16 horas (sólidos). As ovelhas apresentaram as maiores espessuras de gordura, diferindo significativamente dos cordeiros. As medidas morfométricas foram maiores em ovelhas e cordeiros. A relação músculo / gordura dos cortes dos animais nas diferentes fases fisiológicas não apresentou diferenças significativas. Os ovinos pantaneiros apresentam bom potencial para produção de carne, independentemente de seus estágios fisiológicos. As ovelhas se destacaram, apresentando carcaças com bom desempenho considerando seu potencial e maior permanência no rebanho devido à sua função reprodutiva.

Palavras-chave: Abate. Carne ovina. Morfometria. Animais localmente adaptados. Órgãos.

\section{Introduction}

Sheep breeding is an important source of income for low-income farmers in rural areas. Sheep are grazing animals that get most of their nutrient requirements from pasture. They are more economical than other animal species, are resistant to diseases and harsh environmental conditions, are easy to herd, and can effectively benefit from plant resources (Sarı et al., 2019).
The genetic diversity generally observed in locally adapted animals is important as a source of coping with environmental changes. However, for the effective conservation of these, it is essential to demonstrate the productive potential and identify characteristics that need improvement without losing their adaptability acquired over the years of natural selection. 
Locally adapted sheep are being studied by many research institutions around the world, especially because those adapted breeds can be more resistant and productive than foreing breeds. And promote their conservation as a genetic resource, and their insertion in meat productive systems (Vargas et al., 2015; Oliveira et al., 2020).

The locally adapted breed to Mato Grosso do Sul - Brazil, known as Pantaneiro sheep, show excellent adaptation to local environmental conditions and low technology systems, which is a consequence of a long natural selection process (Monteschio et al., 2018). This added local adaptive characteristics and also favorable to several other environments such as small, productive and rustic, which consolidated them as a new breed to be used in the production of sheep meat.

Sheep breeding for meat production offers mostly three groups of animals: lambs (castrated and non-castrated males up to six months of age), wethers and rams (castrated and non-castrated males over six months of age), and cull ewes (females that have lost their reproductive capacity), these animals are finished on pastures or feedlots depending on thesystemused bythe producer (Raineri, Stivari \& Gameiro 2015). Due to this heterogeneous supply of animals for slaughter, the producers maintain the animals for longer periods in their herds in times of low demand. This explains this lack of uniformity, especially when the sheep breeding represents the subsistence of the producer.

These groups may lead to the formation of heterogeneous lots, with animals of different age and sex, and consequently, of different body and physiological development stages. This causes changes, remodeling regions of the body, and the carcass of these animals, affecting the performance and quality of carcass and non-carcass components, which are directly related to the quality of the final products (Osório et al., 2012).

Therefore, the supply of heterogeneous animals for slaughter results in products of different quality, and the productive system cannot slaughter precocious animals. The hypothesis of this research is that uncastrated lambs, castrated lambs and cull ewes, even being of different ages, sexes and coming from different production systems, have similar characteristics respecting the proportional differences in size or that will probably not be noticed by the consumer who receives a only information such as sheep meat or erroneously "mutton", not justifying the difference in price given to the producer. Thus, the objective of this work was to characterize carcass and non-carcass components of an indigenous sheep breed at the three commonly used physiological stages for slaughter, trade, and consumption in Brazil.

\section{Materials and Methods}

All protocols of experimental procedures were approved by the Animal Experimentation Ethics Committee (Protocol 007/2013-CEUA/UFGD), of the Federal University of Grande Dourados (UFGD), Dourados, State of Mato Grosso do Sul, Brazil.

The uncastrated lambs were confined in covered individual stalls of $2 \mathrm{~m}^{2}$, equipped with nipple drinkers and individual troughs. These animals were subjected to 10 days of adaptation to the experimental conditions. Their rations was composed of $80 \%$ of 
concentrate $(16 \%$ crude protein and $75 \%$ total digestible nutrients) and $20 \%$ of roughage (oat hay with $7 \%$ crude protein and $55.6 \%$ total digestible nutrients), with mean consumption per animal of $1.2 \pm 0.096 \mathrm{~kg}$ (concentrate) and $0.299 \pm 0.024 \mathrm{~kg}$ (roughage).

The wethers were kept on pastures with supplementation with the same concentrate offered to the lambs, and the ewes were kept exclusively on pastures without any supplementation before slaughtering (Table 1), adapted from Monteschio et al. (2018).

Slaughter ages were defined in order to simulate the most representative products and farming systems in the Brazilian sheep industry. Different farming systems were established according to input priorities related to different physiological stages. Animals were slaughtered and classified as non- castrated lambs (deciduous teeth) (a), wethers (two teeth) (b) and cull ewes (4-8 teeth) (c) Table 1. The criteria to slaughter lambs (a) and wethers (b) was the body condition, which ranged from 2.5 to 3.0 (Russel, Doney \& Gunn 1969). Cull ewes (c) were slaughtered based on negative pregnancy diagnosis, regardless of their body condition, which ranged from 4.0 to 4.5 (Table 1).
All animals were slaughtered after 16-hours of fasting (solids), following the legislation and regulations of the Industrial and Sanitary Inspection Regulation for Products of Animal Origin (MAPA, 2000). The animals were previously weighed to obtain pre-slaughter body weight (BW). Desensitization was carried out by electronarcosis (8 seconds of 220$\mathrm{V}$ discharge) followed by cutting of jugular veins and carotid arteries with subsequent evisceration. The carcasses were weighed after evisceration to obtain the warm carcass weight (WCW) and warm carcass yield $(W C Y=W C W / B W \times 100)$ and transferred to a cold room at $4^{\circ} \mathrm{C}$ for 24 hours. The cold carcass weight $(\mathrm{CCW})$, cold carcass yield $(\mathrm{CCY}=\mathrm{CCW} /$ BW * 100) and weight loss by cooling (WLC $\left.=(\mathrm{WCW}-\mathrm{CCW} / \mathrm{WCW})^{*} 100\right)$ were obtained according to the methodology described by Cunha et al. (2016). 
Table 1

Centesimal and nutritional composition of experimental diets from 1 to 28 days of age.

\begin{tabular}{|c|c|c|c|}
\hline \multirow[b]{3}{*}{ Number of animals } & \multicolumn{3}{|c|}{ Physiological stages } \\
\hline & Lambs (a) & Wethers (b) & Cull ewes (c) \\
\hline & 11 & 9 & 10 \\
\hline $\begin{array}{l}\text { Bodyweight at } \\
\text { birth (kg) }\end{array}$ & $3.6 \pm 0.9$ & $3.5 \pm 0.7$ & - \\
\hline $\begin{array}{l}\text { Body weight } \\
\text { weaning }(\mathrm{kg})\end{array}$ & $19.0 \pm 4.0$ & $12.5 \pm 1.2$ & - \\
\hline $\begin{array}{l}\text { Weight gain from } \\
\text { birth to slaughter (kg) }\end{array}$ & $0.2 \pm 0.3$ & $0.1 \pm 0.2$ & - \\
\hline $\begin{array}{l}\text { Body weight at } \\
\text { slaughter (kg) }\end{array}$ & $36.0 \pm 4.2$ & $41.8 \pm 5.1$ & $48.3 \pm 4.6$ \\
\hline $\begin{array}{l}\text { Body condition at } \\
\text { slaughter }(1-5)\end{array}$ & $2.8 \pm 0.2$ & $2.9 \pm 0.2$ & $3.9 \pm 0.4$ \\
\hline Breeding system & $\begin{array}{l}\text { Ad libitum creep } \\
\text { feeding (feedlot) } \\
\text { from birth to } \\
\text { weaning } \\
\text { (60-90 days) }\end{array}$ & $\begin{array}{c}\text { Ad libitum creep feeding on } \\
\text { birth to weaning (60-90 days) } \\
\text { on Cynodon spp. (Tifton } 85) \\
\text { pasture with concentrate } \\
\text { supplementation during } \\
\text { the last two months before } \\
\text { slaughter }\end{array}$ & $\begin{array}{c}\text { Animals with at least one } \\
\text { calving, discarded after } \\
\text { negative diagnosis of } \\
\text { pregnancy in two consecutive } \\
\text { breeding seasons, maintained } \\
\text { in pastures of Brachiaria } \\
\text { Brizantha }\end{array}$ \\
\hline
\end{tabular}

(a) Castrated and non-castrated males up to six months of age; (b) castrated and non-castrated males over six months of age; (c) females that have lost their reproductive capacity.

After slaughter, the carcasses were stored in a cold room at $4^{\circ} \mathrm{C}$ during 24 hours. All samples were analyzed with one replicate, and the final value of each variable was determined calculating a simple mean for each variable. Carcass morphometry was performed according to Merwe, Brand \& Hoffman et al. (2020). The fat cover thickness and Longissimus dorsi muscle area were measured in the left half carcass to determine the loin eye area according to the methodology described by Pálsson (1939).

The white viscera (esophagus-tongue, rumen-reticulum, omasum-abomasum, large intestine, small intestine, bladder, and renal pelvic fat), red viscera (trachea-lung, heart, kidneys, liver-gallbladder, spleen, and diaphragm), and external body components (head, foot, skin, omentum, and blood) were evaluated according to the methodology described by Panea, Ripoll, Albertí, Joy \& Teixeira (2012) with adaptations. The absolute weights of these components were measured immediately after evisceration, the omasumabomasum, large intestine, and small intestine were weighed, full and empty, they were emptied by hand washing these organs in running water. Subsequently, the relative weight of each of these components about the empty body weight was calculated as a percentage.

The 44 variables were arranged arbitrarily in five issue groups (Thematic group of variables $(\mathrm{Tg}))$ : carcass yield $(\operatorname{Tg} 1)(8 n=$ 
body score, pre-slaughter body weight $(\mathrm{kg})$, warm carcass yield (\%), cold carcass yield (\%), weight loss by cooling (\%), subcutaneous fat thickness $(\mathrm{mm})$, loin eye area $\left.\left(\mathrm{cm}^{2}\right)\right)$; morphometry $(\mathrm{Tg} 2)(8 \mathrm{n}=$ external length $(\mathrm{cm})$, inner length $(\mathrm{cm})$, leg length (cm), rump width (cm), leg depth $(\mathrm{cm})$, chest depth(cm), carcass compacity index $\left(\mathrm{kg} \mathrm{cm}^{-1}\right)$, leg compacity index $\left.\left(\mathrm{kg} \mathrm{cm}^{-1}\right)\right)$; white viscera $(\operatorname{Tg} 3)(14 \mathrm{n}=$ bladder $(\%)$, esophagus-tongue (\%), small intestine length (cm), full rumen-reticulum (\%), full omasumabomasum (\%), full small intestine (\%), full large intestine (\%), empty rumen-reticulum (\%), empty omasum-abomasum (\%), empty small intestine (\%), empty large intestine (\%), sum of white viscera in $\mathrm{CCW}(\%)$, sum of white viscera in full body weight (FBW) (\%), sum of white viscera in empty body weight (EBW) (\%)); red viscera (Tg4) $(8 n=$ trachea-lung (\%), heart (\%), liver-gallbladder (\%), spleen (\%), diaphragm (\%), kidney (\%), sum of red viscera in EBW (\%), sum of red viscera in CCW(\%)); sum of noncarcass components $(\mathrm{Tg} 5)(6 \mathrm{n}=$ skin $(\%)$, head (\%), foot (\%), blood (\%), omentum (\%), noncarcass components (\%)).

The data were analyzed through two approaches: univariate and multivariate. Univariate approach: descriptive statistics and analysis of variance were performed using the software SAS 9.2 (SAS Institute, Cary, NC, USA), obtaining the means and the effect $(p<0.05)$ of physiological stages (fixed effect) using the Tukey's test to described differences between means of the analyzed variables. Multivariate approach: the DISCRIM procedure was used to test the groups discriminating capacity of variables on lambs, wethers and cull ewes samples. The STEPDISC procedure was used to identify three smaller variables groups (selection summary of variables Ss1 (lambs versus wethers), Ss2 (wethers versus cull ewes) and, Ss3 (wethers versus cull ewes) with the greatest contribution to the physiological stages of discrimination. These sets of variables (Ss1, Ss2 and, Ss3) were used individually in a new discriminant analysis to test their animal's discriminant capacity of different physiological stages. The magnitude of the difference between the physiological stages was evaluated using the Mahalanobismetric distance.

\section{Results and Discussion}

The physiological stages affected the carcass yield variables $(p<0.05)$. Cull ewes had the highest values for body score and the highest pre-slaughter body weight. The cold carcass weight and yield in the three physiological stages were on mean above $45 \%$ (Table 2). Fat thickness was negatively correlated with weight loss by cooling, wethers and cull ewes with greater carcass subcutaneous fat thickness had greater protection against the deleterious effects of cooling (Table 2), and lambs presented the highest weight losses by cooling since their fat thickness was $75 \%$ lower.

To both, lambs and cull ewes the carcass yield variables did not differ with the exception of the leg yield in relation to the cold carcass (Table 3). Lambs presented results equal to those of whether. For this characteristic, the cull ewes presented the lowest results.

The body score and pre-slaughter bodyweight presented no direct relationship with warm, and cold carcass yield, and the lambs with lower body weight and score, and cull ewes presented the highest yields. 
The animal's aging increased its preslaughter body weight and carcass yields. The greater the animal's age, the greater the slaughter weight and the carcass weight, yielding superior carcasses, as expected (Kim et al., 2020). Thus, the bodyweight is not a determining factor of carcass yield for these breed, and the bodyweight is an inadequate animal description of the value for meat production and is not the best criterion for trade this meat (Osório et al., 2012).

\section{Table 2}

Carcass components ( $\mathrm{Tg} 1$ group - carcass yield variables) of sheep as a function of their different physiological stages lambs (a), wethers (b) and cull ewes(c).

\begin{tabular}{|c|c|c|c|c|c|c|}
\hline \multirow{2}{*}{ Parameters } & \multicolumn{3}{|c|}{ Different physiological stages } & \multirow{2}{*}{ Means } & \multirow{2}{*}{ Error } & \multirow{2}{*}{ P-value } \\
\hline & Lambs & Wethers & Cull ewes & & & \\
\hline Body Score (1-5) & $2.8 b$ & $2.9 b$ & $3.9 a$ & 3.2 & 1.7 & $<0.01$ \\
\hline Pre-Slaughter Body Weight Score (kg) & $36.0 \mathrm{c}$ & $41.8 b$ & 48.3a & 47.7 & 3.4 & $<0.01$ \\
\hline Warm Carcass Yield (\%) & $49.4 a$ & $45.0 b$ & $48.4 a$ & 47.7 & 2.7 & 0.03 \\
\hline Cold Carcass Yield (\%) & $47.5 a$ & $43.2 b$ & 46.3a & 45.8 & 2.9 & 0.09 \\
\hline Weight Loss by Cooling (\%) & $4.0 a$ & $3.4 a b$ & $3.1 b$ & 3.5 & 0.6 & 0.02 \\
\hline Subcutaneous Fat Thickness (mm) & $0.9 a$ & $2.8 b$ & $3.7 b$ & 2.5 & 0.1 & $<0.01$ \\
\hline Loin Eye Area $\left(\mathrm{cm}^{2}\right)$ & 16.5 & 14.8 & 14.4 & 15.3 & 0.8 & 0.11 \\
\hline
\end{tabular}

Means followed by the same letters do not differ by the Tukey's test at $5 \%$.

\section{Table 3}

Carcass morphometry ( $\mathrm{Tg} 2$ group - carcass morphometry variables) of sheep as a function of their different physiological stages lambs (a), wethers (b) and cull ewes(c).

\begin{tabular}{|c|c|c|c|c|c|c|}
\hline \multirow{2}{*}{ Parameters } & \multicolumn{3}{|c|}{ Different physiological stages } & \multirow{2}{*}{ Means } & \multirow{2}{*}{ Error } & \multirow{2}{*}{ P-value } \\
\hline & Lambs & Wethers & Cull ewes & & & \\
\hline External Length $(\mathrm{cm})$ & $59.6 b$ & $66.2 a$ & $65.1 a$ & 63.4 & 4.5 & 0.01 \\
\hline Inner Length (cm) & $60.7 b$ & $68.3 a$ & $64.2 a$ & 64.14 & 4.2 & 0.02 \\
\hline Leg Length (cm) & 40.6 & 41.1 & 41.4 & 40.93 & 2.2 & 0.55 \\
\hline Rump Width (cm) & $63.6 b$ & $66.8 \mathrm{~b}$ & $73.5 a$ & 67.72 & 3.4 & $<0.01$ \\
\hline Leg Depth (cm) & $11.8 b$ & $13.8 a$ & $15.1 \mathrm{a}$ & 13.3 & 2.1 & $<0.01$ \\
\hline Chest Depth (cm) & $25.8 \mathrm{c}$ & $28.0 b$ & $30.0 a$ & 27.6 & 1.1 & $<0.01$ \\
\hline Carcass Compacity Index ( $\left.\mathrm{kg} \mathrm{cm}^{-1}\right)$ & $0.28 b$ & $0.27 b$ & $0.36 a$ & 0.30 & 0.0 & $<0.01$ \\
\hline Leg Compacity Index $\left(\mathrm{kg} \mathrm{cm}^{-1}\right)$ & 0.60 & 0.61 & 0.60 & 0.61 & 0.1 & 0.63 \\
\hline
\end{tabular}

Means followed by the same letters do not differ by the Tukey's test at $5 \%$. 
The mean carcass compacity index found was higher than that this found in Santa Ines breed by Jucá et al. (2016), who reported carcass compacity index of $0.24 \mathrm{kgcm}^{-1}$ in lambs, and by Silva et al. (2016), who found compacity index of 0.12 to $0.29 \mathrm{kgcm}^{-1}$.

Similar carcass yields between the three physiological stages even with different body scores can be explained based on Owens, Dubeski \& Hanson (1993) who highlight that once physiological maturity is reached, muscle mass reaches its maximum and from this point on, there is an increase in the development of adipose tissue in a greater proportion.

The loin eye area was similar in the three physiological stages. An inverse correlation between loin eye area (LEA) and subcutaneous fat thickness (SFT) was found. Although the stages did not differ in this parameter, the results showed LEA of 16.5 and SFT of $0.9 \mathrm{~cm}$ for lambs, LEA of 14.8 and SFT of $2.8 \mathrm{~cm}$ for wethers; and LEA of 14.4 and SFT of $3.7 \mathrm{~cm}$ for cull ewes. In the current study the mean loin eye area (LEA) was $15.3 \mathrm{~cm}^{2}$, which is similar to that found by Vargas et al. (2014) and higher than those reported by Cunha et al. (2016). The LEA differ from lambs to cull ewe.

The morphometry variables differed between physiological stages $(p<0.05)$. The morphometry of lamb carcasses presented the lowere values for external and internal lengths (IL), rump width, and leg, and chest depths (Table 3). Cull ewes presented greater values for rump width (cm) (Table 3) due to their reproductive function, an adaptation for the birth of their offspring.

Cull ewes and wethers had carcasses with greater IL (64.2 and $68.3 \mathrm{~cm}$, respectively), external length (65.1 and $66.2 \mathrm{~cm}$, respectively), and leg depth (15.1 and $13.8 \mathrm{~cm}$, respectively). The carcasses of the cull ewes had greater chest depth and greater compacity (Table 3).

Cull ewes presented greater croup width due to their reproductive function, an adaptation for the birth of their offspring. The wethers (12 months) and cull ewes (46 months) presenting similar external and internal length of carcasses, this result, can be attributed to the greater body development of these animals, despite the different animal's sex and age, this similarity indicates that the body growth of these animals stabilize at 12 months of age, explaining their carcass length and deposition of subcutaneous fat.

The evaluation of the white viscera (non-carcass components) showed that most of the variables were affected by the physiological stage $(p<0.01)$ (Table 4). Cull ewes and wethers had the highest internal fat percentages (Table 4), confirming the increase of this component with increasing animal's maturity. 
Table 4

Non-carcass components of Pantaneiro sheep at different physiological stages lambs (a), wethers (b) and cull ewes(c).

\begin{tabular}{|c|c|c|c|c|c|c|}
\hline \multirow{2}{*}{ Parameters } & \multicolumn{3}{|c|}{ Different physiological stages } & \multirow{2}{*}{ Means } & \multirow{2}{*}{ Error } & \multirow{2}{*}{ P-value } \\
\hline & Lambs & Wethers & Cull ewes & & & \\
\hline \multicolumn{7}{|l|}{ Write viscera variable- Group $\mathrm{TG}_{3}$} \\
\hline Bladder*(\%) & 0.09 & 0.06 & 0.04 & 0.07 & 0.37 & 0.57 \\
\hline Esophagus-tongue*(\%) & 0.46 & 0.48 & 0.44 & 0.46 & 0.32 & 0.80 \\
\hline Internal Fat * (\%) & $1.4 b$ & $2.0 \mathrm{ab}$ & $3.1 \mathrm{a}$ & 2.2 & 0.37 & $<0.01$ \\
\hline Small intestine length (cm) & 24.4 & 25.8 & 23.1 & 24.4 & 0.09 & 0.27 \\
\hline Full rumen-reticulum*(\%) & $13.0 b$ & $15.0 \mathrm{ab}$ & $17.0 a$ & 14.8 & 3.2 & 0.04 \\
\hline Full omasum-abomasum(\%) & $1.4 b$ & $2.1 \mathrm{a}$ & $2.1 \mathrm{a}$ & 1.9 & 0.5 & 0.01 \\
\hline Full small intestine*(\%) & $3.1 \mathrm{a}$ & $3.2 \mathrm{a}$ & $2.4 b$ & 2.9 & 0.6 & 0.02 \\
\hline Full large intestine*(\%) & $4.3 b$ & $4.0 b$ & $5.3 a$ & 4.6 & 0.9 & $<0.01$ \\
\hline Empty rumen-reticulum*(\%) & 2.4 & 2.6 & 2.6 & 2.5 & 0.6 & 0.80 \\
\hline Empty omasum-abomasum(\%) & $0.8 b$ & $1.0 \mathrm{ab}$ & $1.1 \mathrm{a}$ & 1.0 & 0.3 & 0.02 \\
\hline Empty small intestine*(\%) & $2.2 \mathrm{a}$ & $1.6 b$ & $1.3 b$ & 1.7 & 0.3 & 0.04 \\
\hline Empty large intestine*(\%) & $2.6 a$ & $1.6 b$ & $3.1 \mathrm{a}$ & 2.4 & 0.9 & $<0.01$ \\
\hline White viscera** (\%) & $15.9 a$ & $13.7 b$ & $17.7 a b$ & 15.8 & 1.4 & 0.04 \\
\hline White viscera*** (\%) & 8.5 & 7.0 & 8.5 & 8.1 & 0.21 & 0.05 \\
\hline White viscera*(\%) & 15.2 & 13.2 & 15.6 & 14.8 & 0.13 & 0.14 \\
\hline \multicolumn{7}{|l|}{ Red viscera variable - Group $\mathrm{TG}_{4}$} \\
\hline Trachea-lung* (\%) & 1.9 & 2.4 & 2.0 & 2.1 & 0.4 & 0.07 \\
\hline Heart* (\%) & $0.5 b$ & $0.6 a$ & $0.5 a b$ & 0.5 & 0.1 & 0.03 \\
\hline Liver-gallbladder* (\%) & $1.6 a$ & $1.8 \mathrm{a}$ & $1.2 b$ & 1.6 & 0.2 & 0.01 \\
\hline Spleen* $(\%)$ & 0.2 & 0.2 & 0.2 & 0.2 & 0.1 & 0.10 \\
\hline Diaphragm* (\%) & 0.4 & 0.5 & 0.5 & 0.5 & 0.1 & 0.41 \\
\hline Kidney* $(\%)$ & $0.3 a$ & $0.3 b$ & $0.2 \mathrm{c}$ & 0.3 & 0.0 & 0.01 \\
\hline Red viscera* (\%) & 5.8 & 5.0 & 4.6 & 4.8 & 0.6 & 0.60 \\
\hline Red viscera** (\%) & 10.8 & 9.7 & 9.6 & 9.7 & 3.2 & 0.10 \\
\hline \multicolumn{7}{|c|}{ Non-carcass components variable - Group $\mathrm{TG}_{5}$} \\
\hline Skin* (\%) & 11.6 & 13.5 & 12.5 & 12.5 & 1.1 & 0.10 \\
\hline Head* $\left.^{*} \%\right)$ & 5.2 & 5.0 & 5.0 & 5.1 & 0.7 & 0.70 \\
\hline Foot* $(\%)$ & $2.4 a$ & $2.5 a$ & $2.0 \mathrm{~b}$ & 2.0 & 0.2 & $<0.01$ \\
\hline Blood* (\%) & 4.0 & 4.6 & 4.4 & 4.4 & 0.5 & 0.06 \\
\hline Omentum* (\%) & $2.4 b$ & $3.5 a b$ & 4.3a & 3.4 & 1.4 & $<0.01$ \\
\hline Non-carcass components* (\%) & $49.4 b$ & $67.1 \mathrm{a}$ & $62.1 \mathrm{ab}$ & 58.9 & 0.2 & $<0.01$ \\
\hline
\end{tabular}

*Adjusted to empty body weight; **adjusted to cold carcass weight; ***adjusted to body weight. Means followed by the same letter do not differ by the Tukey's test at $5 \%$. 
Analyzing the internal fat percentage, the large age difference between animals like wethers (12 months) and cull ewes (46 months), and their similar percentage of internal fat ( 2.04 and $3.6 \%$, respectively), indicates that indigenous Pantaneiro sheep present a more pronounced internal fat deposition after six months of age. Thus, producers must pay attention to this aspect since fat deposition on the carcasses is not desirable. Different from subcutaneous fat, it has no specific function nor adds value to the carcass, and increases energy requirements for body maintenance due to the higher metabolic rate of the adipose tissue, wasting energy supplied by the diet, since this fat is not used for human consumption (Toldrá, Aristoy, Mora, \& Reig 2012).

The ratio between full white viscera (reticulum-rumen and omasum-abomasum) and empty body weight was higher in wethers and ewes, ewes had the highest ratio of the large intestine, and lambs and wethers had the highest ratios of the small intestine (Table 4). The ratio between empty white viscera and empty body weight in cull ewes and lambs was higher for the omasum-abomasum and large intestine, lambs also had the highest ratio of the empty small intestine (Table 4).

The ratio between white viscera and cold carcass weight was lower in wethers and higher in the other stages evaluated (lambs and cull ewes) (Table 4). These organs were not necessarily larger in these animals due to their higher body weight or age since more than half of the variables were similar in lambs and cull ewes stages.

In relation to the ratio between full white viscera (reticulum-rumen and omasumabomasum) and empty body weight, wethers, and cull ewes presenting higher values. These organs are linked to food consumption and digestion capacity by these animals. Their food consumption capacity increases with age since the greater the body the greater the amount of food needed for its maintenance. The ratio between empty white viscera and EBW in cull ewes and lambs was higher for the omasum-abomasum and large intestine, lambs also had the highest ratio of the empty small intestine.

The results of non-carcass components (Table 4) showed the effect of the physiological stage only on the ratios between the foot, omentum, and non-carcass components and pre-slaughter body weight $(p<0.05)$. The lamb and wethers physiological stages had the highest foot ratios (Table 4). The ratio of skin (skin-wool) was similar in the lamb, wethers and cull ewe $(p<0.05)$ stages, but it was the non-carcass component of greater proportion (Table 4).

Omental and renal fat weight and ratio were higher and similar in wethers and cull ewes (Table 4). These results may also be connected to their higher empty body weight, and age compared to stage A represented by lambs younger than seven months of age.

The wethers had the highest heart ratio, and this ratio in lambs and ewes were similar $(p<0.05)$ (Table 4). The liver-gallbladder and kidney to empty body weight ratio were lower in cull ewes $(p<0.05)$ (Table 4$)$.

The skin was the non-carcass component of greater proportion in our study. Being a by-product of meat production that receives little attention, despite representing $10 \%$ to $12 \%$ of the sheep value. Their skin is a product of great economic value after processing, and when it has a good quality, it 
may represent the difference between profit and loss in the animal's sale (Morehead, 2014).

The omental and renal fat weight and ratio were higher and similar in wethers and cull ewes. These results may also be connected to their higher empty body weight, and age compared to lambs, represented by lambs younger than seven months of age. The dynamic interplay between fat storage and mobilization, depending on metabolizable energy intake, and therefore, variable body condition score could have some practical implications for feeding management under tropical conditions (Chay-Canul, Ayala-Burgos, Ku-Vera, Magaña-Monforte \& Tedeschi 2011). Fat deposition in tropical sheep is considered as an adaptive response of animals to a hazardous environment and is a valuable energy reserve for the animal for periods of food migration (Moradi, Nejati-Javaremi, Moradi-Shahrbabak, Dodds \& McEwan 2012).

The pattern of fat accumulation in Pelibuey ewes (tropical Mexico) adapted to warm climates such as those prevailing in tropical regions, may be utilized to implement feeding and supplementation strategies to cope with the negative effects of nutritional fluctuations in tropical areas (Chay-Canul et al., 2011).

The use of different variables groups showed the greatest metrical distances (Mahalanobis) between lambs and cull ewes 286 (Tg1); 8.3 (Tg2); 48 (Tg3); 49 (Tg4); 45 (Tg5). The metric distances between lambs and wethers were 125 ( $\operatorname{Tg} 1) ; 6$ (Tg2); 12 (Tg3); 13 (Tg4); 19 (Tg5), and the metric distances between wethers and cull ewes were $48(\operatorname{Tg} 1)$; 7.3 (Tg2); 22 (Tg3); 33 (Tg4); 11 (Tg5). Table 2 presents the data from group 1, Table 3 the data from group 2; and Table 4 are the groups 3; 4; and 5.

The carcass yield $(\operatorname{Tg} 1)$ and white viscera (Tg3) variables presented perfect discrimination (100\%) between the three physiological stages. The variables of red viscera (Tg4) had a sample of wethers classified as cull ewe (100\%, 88.8\%, 100\%). A small percentage of error in the animal's classification by the morphometric variables (Tg2) (100\%; 89\%; 90\%) and the variables related to weights of non-carcass components (Tg5) (80\%; 100\%; 80\%) (Table 4).

The variables determination with the greatest contribution to the discrimination of the physiological stages resulted in three groups of variables: Ss1 (lambs versus wethers), Ss2 (lambs versus cull ewes) and Ss3 (wethers versus cull ewe) (Table 5).

The Ss1 group - lambs versus wethers presented perfect discrimination (100\%) between lambs and wethers, and three classification errors between wethers and ewes (Table 5). The Ss2 group - lambs versus cull ewes presented perfect discrimination (100\%) between lambs and cull ewes, and a classification error between wethers and cull ewes. The Ss3 group- wethers versus cull ewe had perfect discrimination (100\%) of the physiological stages. Thus, Ss1 can differentiate lambs from wethers, Ss2 can differentiate lambs from ewes, and Ss3 can differentiate the three physiological stages. 


\section{Table 5}

Discrimination of Pantaneiro sheep at different physiological stages lambs (a), wethers (b) and cull ewes(c) by red viscera variables (Tg4).

\begin{tabular}{ccccc|} 
Physiological Stages & Lambs & Wethers & Cull ewes & Total \\
\hline \multirow{2}{*}{ Lambs } & 11 & 0 & 0 & 11 \\
& 100 & 0 & 0 & 100 \\
Wethers & 0 & 8 & 1 & 9 \\
Cull ewes & 0 & 88.9 & 11.1 & 100 \\
& 0 & 0 & 10 & 10 \\
Total & 0 & 0 & 100 & 100 \\
& 11 & 8 & 11 & 30 \\
& 36.7 & 26.7 & 36.7 & 100
\end{tabular}

The variables with the greatest contribution to the discrimination of carcass and non- carcass components of Pantaneiro sheep at different physiological stages (Table 5). To lambs versus wethers was, Chest depth (cm); Full Omasum-abomasum relative weight*; Omentum relative weight*; Lung trachea relative weight*. To lambs versus cull ewe was, Body score; Chest depth (cm); leg compacity; empty large intestine relative weight*; leg depth (cm); and Internal length (cm). To wethers versus cull ewe was, Body score; loin eye area $(\mathrm{cm})$; lung-trachea weight*; Chest depth (cm); Skin relative weight*; Subcutaneous fat thickness $(\mathrm{mm})$. In relation to the empty body weight $\left(\mathrm{EBW}^{*}\right)$.

In this study, the physiological stages of lambs and wethers had the highest foot ratios. The foot and head to empty body weight ratio decrease with increasing size, weight, and age. The head, foot, and skin growth are affected by the animal's age, weight, race, and gender. Esteves et al. (2018) working with Santa Ines hair ewes aged 6 to 48 months, observed that younger animals had higher leg yield. As age increases, the commercial cuts number has decreased and the loss of quality characteristics has increased.

Regarding the total non-carcass components to empty body weight ratio was correlated with the animal's age and size, and lower in lambs. The representativeness of noncarcass components of animals in this stage is high, but it did not compromise the carcass yield, since the animals had similar carcass yield, and the wethers were different because of their physiological stage, presenting lower cold carcass yield, with only about $8 \%$.

According to Gomes et al. (2020), organs, such as heart and lungs, maintain their integrity because they are prioritized in the use of nutrients, regardless of the nutrition level. It's natural lungs and trachea be bigger in cull ewes because of the lactation capacity.

Fontenele et al. (2010) evaluated the metabolizable energy rates effect in feeds on internal organ weights (gastrointestinal components) of Santa Ines sheep and found a linear increase in their liver weight with increasing energy rates in their feed. The liver is important for various metabolic processes 
and has active participation in energy and protein metabolism.

According to Gomes et al. (2020), the visceral organ's mass may affect the animal's nutritional efficiency and the nutrients used by various tissues of the body, thus, studies on this organs may be useful for the evaluation of the effects of nutrition on growth, and optimize the various feeds use. Regarding indigenous Pantaneiro sheep breeding, adding value to the non-carcass components is an interesting alternative, cull ewes present this potential besides their reproductive function, reinforcing the need for further studies.

In general, the percentage of discrimination was high, regardless of the thematic group. Thus, different groups of variables carcass and non-carcass components can show differences between physiological stages, probably due to the production system and animal physiology.

The body score has great practical use in farms, the carcass yield, and white viscera percentages in relation to the empty body weight are useful in industries, and the fat thickness and the loin eye area are related to the quality of commercial cuts (consumer market). Thus, Ss3 (wethers versus cull ewes) is the choice group for discrimination of physiological stages for meat products. The differences in the energy requirements for animal maintenance and other aspects of the production system and, the animal's physiology shows the importance of these variables for the physiological stages of discrimination. The use of thematic groups of variables $(\mathrm{Tg})$ and a posteriori selected variables (stepwise selection) are capable of discriminating the three physiological stages evaluated.
The results found show the potential of this genetic resource (indigenous Pantaneiro sheep) for sheep meat production. The differences found between the physiological stages can be considered for the meat products processing and industrialization, and marketing strategies for commercial cuts. Considering the prospect of promoting the indigenous Pantaneiro sheep meat production, the animal's physiological stage must be considered in the development of a seal of quality, indicating origin, geographical origin, and quality control.

\section{Conclusion}

The indigenous Pantaneiro sheep have good carcass yield and potential for meat production when compared to consolidated breeds, regardless of their physiological stage. What is important to breed characterization. Pantaneiro cull ewes present great potential for meat production and non-carcass components, besides their reproductive function. The growth and development of noncarcass components of indigenous Pantaneiro sheep are little affected by their physiological stage.

\section{Acknowledgments}

The authors would like to thank the Brazilian funding institutes UFGD, CAPES, CNPq, and PRONEM - FUNDECT, Term number 083/2015, SIAFEM: 024465.

\section{Conflict of Interest}

The authors declare no conflict of interest. 


\section{References}

Castro, D. P. V., Yamamoto, S. M., Araújo, G. G. L., Pinheiro, R. S. B., Queiroz, M. A. A., Albuquerque, Í. R. R., \& Moura, J. H. A. (2017). Influence of drinking water salinity on carcass characteristics and meat quality of Santa Inês lambs. Tropical Animal Health and Production, 49(6), 1095-1100. doi: 10.1007/s11250-017$1289-5$

Chay-Canul, A. J., Ayala-Burgos, A. J., Ku-Vera, J. C., Magaña-Monforte, J. G., \& Tedeschi, L. O. (2011). The effects of metabolizable energy intake on body fat depots of adult Pelibuey ewes fed roughage diets under tropical conditions. Tropical Animal Health and Production, 43(5), 929-936. doi: 10.1007/s11250-011-9785-5

Cunha, C. M., Cornélio, T. C., Fernandes, A. R. M., Seno, L. O., Ricardo, H. A., Osório, J. C. S.,... Oliveira, E. A. (2016). Características da carcaça e qualidade da carne de cordeiros Pantaneiros alimentados com teores crescentes de glicerina bruta. Revista Brasileira de Saúde e Produção Animal, 17(4), 729-743. doi: 10.1590/s15 19-99402016000400016

Esteves, G. I. F., Peripolli, V., Menezes, A. M., Louvandini, H., Silva, A. F., Cardoso, C. C., \& McManus, C. (2018). Carcass characteristics and meat quality in cull ewes at different ages. Ciência Animal Brasileira, 19(1-11), e-33874. doi: 10.15 90/1809-6891v19e-33874

Fontenele, R. M., Pereira, E. S., Pimentel, P. G., Mizubuti, I. Y., Monte, A. L. de S., Candido, M. J. D.,... Rocha, J. N., Jr. (2010). Níveis de energia metabolizável em rações de ovinos Santa Inês: peso dos órgãos internos e do trato digestório. Semina: Ciências Agrárias, 31(4), 1095-1104. doi: 10.5433/1679-0359.2010v31n4p1095

Gomes, R. N., Paula, T. A., Carvalho, F. F. R., Cordeiro, E. H. A., Nascimento, H. F. A., Mendes, G. O.,... Véras, A. S. C. (2020). Low-purity crude glycerin as a nutrient substitute for corn: the effect on yields of goat organs and viscera. Acta Scientiarum. Animal Sciences, 42, e48650. doi: 10.4025/actascianimsci.v42 i1.48650

Jucá, A. F., Faveri, J. C., Melo, G. M., Fo., Ribeiro, A. L., Fo., Azevedo, H. C., Muniz, E. N.,... Pinto, L. F. B. (2016). Effects of birth type and family on the variation of carcass and meat traits in Santa Ines sheep. Tropical Animal Health and Production, 48(2), 435443. doi: 10.1007/s11250-015-0971-8

Kim, D.-G., Shim, J.-Y., Cho, B.-K., Wakholi, C., Seo, Y., Cho, S., \& Lee, W.-H. (2020). Discrimination study between carcass yield and meat quality by gender in Korean native cattle (Hanwoo). Asian-Australasian Journal of Animal Sciences, 33(7), 12021208. doi: 10.5713/ajas.19.0472

MAPA (2000). Ministério da Agricultura, Pecuária e Abastecimento. Instrução Normativa no 3, de 17 de janeiro de 2000. Aprova o regulamento técnico de métodos de insensibilização para o abate humanitário de animais de açougue. Diário Oficial da República Federativa do Brassil.

Merwe, D. A. V. D., Brand, T. S., \& Hoffman, L. C. (2020). Slaughter characteristics of feedlot-finished premium south african lamb: effects of sex and breed type. Foods, 9(5), 648-64. doi: 10.3390/foods9050648 
Monteschio, J. O., Burin, P. C., Leonardo, A. P., Fausto, D. A., Silva, A. L. A., Ricardo, H. A.,... Vargas, F. M., Jr. (2018). Different physiological stages and breeding systems related to the variability of meat quality of indigenous Pantaneiro sheep. PLoS One, 13(2), e0191668. doi: 10.1371/ journal.pone.0191668

Moradi, M. H., Nejati-Javaremi, A., MoradiShahrbabak, M., Dodds, K. G., \& McEwan, J. C. (2012). Genomic scan of selective sweeps in thin and fat tail sheep breeds for identifying of candidate regions associated with fat deposition. BMC Genetics, 13(1), 10. doi: 10.1186/1471-21 56-13-10

Morehead, S. (2014). The Sheep Value Chain and 'Wool Out' Sheepskin as a Sustainable Material. In: Transition: Re-thinking textiles and surfaces, 26-27 November 2014, Huddersfield.

Oliveira, J. A., Egito, A. A., Crispim, B. A., Vargas, F. M., Jr., Seno, L. O., \& Barufatti, A. (2020). Importance of naturalized breeds as a base for the formation of exotic sheep (Ovis aries) breeds in tropical altitude regions. Genetics and Molecular Biology, 43(2), e20190054. doi: 10.1590/1678-46 85-gmb-2019-0054

Osório, J., Osório, M., Fernandes, A., Seno, L., Ricardo, H., Rossini, H., \& Orrico, M., Jr. (2012). Criteria for animal slaughter and the meat quality. Agrarian, 5(18), 433-443.

Owens, F. N., Dubeski, P., \& Hanson, C. F. (1993). Factors that alter the growth and development of ruminants. Journal of Animal Science, 71(11), 3138-3150. doi: 10.2527/1993.71113138x
Pálsson, H. (1939). Meat qualities in the sheep with special reference to Scottish breeds and crosses. The Journal of Agricultural Science, 29(4), 544-626. doi: 10.1017/ S0021859600052242

Panea, B., Ripoll, G., Albertí, P., Joy, M., \& Teixeira, A. (2012). Atlas de disección de la canal de los rumiantes. Atlas of dissection of ruminant's carcass. (pp. 5-105). ITEA Informacion Tecnica Economica Agraria. 108:1

Raineri, C., Stivari, T. S. S., \& Gameiro, A. H. (2015). Development of a cost calculation model and cost index for sheep production. Revista Brasileira de Zootecnia, 44(12), 443-455. doi: 10.1590/ S1806-92902015001200005

Russel, A. J. F., Doney, J. M., \& Gunn, R. G. (1969). Subjective assessment of body fat in live sheep. The Journal of Agricultural Science, 72(3), 451-454. doi: 10.1017/ S0021859600024874

Sarı, M., Aksoy, Y., Önk, K., Erinç, H., Işık, S. A., \& Tilki, M. (2019). Effects of genotype and fattening system on the quality of male lamb meat - Part 1: technological properties and carcass measurements. Archives Animal Breeding, 62(2), 605614. doi: 10.5194/aab-62-605-2019

Silva, A. C. F., Costa, H. H. A., Peres, M. C. R., Costa, A. C., Sousa, D. R., Batista, A. S. M., \& Landim, A. V. (2016). Meat quality of Morada Nova lambs subjected to different feeding regimes. Semina Ciências Agrárias, 37(2), 911-919. doi: 10.5433/1679-0359.2016v37n2p911

Statistical Analysis System Institute (2008). System for Microsoft Windows. Cary, NC, USA: SAS Institute.: release 9.2. SAS Institute. 
Toldrá, F., Aristoy, M.-C., Mora, L., \& Reig, M. (2012). Innovations in value-addition of edible meat by-products. Meat Science, 92(3), 290-296. doi: 10.1016/j. meatsci.2012.04.004

Vargas, F. M., Jr., Martins, C. F., Pinto, G. S., Ferreira, M. B., Ricardo, H. A., Leonardo, A. P.,... Teixeira, A. (2015). Carcass measurements, non-carcass components and cut production of local Brazilian Pantaneiro sheep and crossbreeds of Texel and Santa Inês with Pantaneiro. Small Ruminant Research, 124, 55-62. doi: 10.1016/j.smallrumres.2014.12.007
Vargas, F. M., Jr., Martins, C. F., Santos Pinto, G., Ferreira, M. B., Ricardo, H. A., Leão, A. G.,... Teixeira, A. (2014). The effect of sex and genotype on growth performance, feed efficiency, and carcass traits of local sheep group Pantaneiro and Texel or Santa Inês crossbred finished on feedlot. Tropical Animal Health and Production, 46(5), 869-875. doi: 10.1007/s11250014-0579-4 